\title{
Critical Social Studies
}

\section{Editors: JOCK YOUNG and PAUL WALTON}

The contemporary world projects a perplexing picture of political, social and economic upheaval. In these challenging times the conventional wisdoms of orthodox social thought whether it be sociology, economics or cultural studies become inadequate. This series focuses on this intellectual crisis, selecting authors whose work seeks to transcend the limitations of conventional discourse. Its tone is scholarly rather than polemical, in the belief that significant theoretical work is needed to clear the way for a genuine transformation of the existing social order.

Because of this, the series will relate closely to recent developments in social thought, particularly to critical theory - the emerging European tradition. In terms of specific topics, key pivotal areas of debate will be selected - for example, mass culture, inflation, problems of sexuality and the family, the nature of the capitalist state, natural science and ideology. The scope of analysis will be broad: the series will attempt to break the existing arbitrary divisions between the social studies disciplines. Its aim is to provide a platform for critical social thought (at a level quite accessible to students) to enter into the major theoretical controversies of the day. 


\title{
Critical Social Studies
}

\author{
PUBLISHED
}

Trade Unions and the Media Peter Beharrell and Greg Philo (eds)

Beyond the Sociology of Conflict David Binns

A Theory of Semiotics Umberto Eco

Capitalism in Crisis: Inflation and the State Andrew Gamble and Paul Walton

The Dialectic of Ideology and Technology Alvin W. Gouldner

The Future of Intellectuals and the Rise of the New Class Alvin W. Gouldner
Policing the Crisis Stuart Hall, Chas Critcher, Tony Jefferson, John Clarke and Brian Roberts

The Political Economy of Science Hilary Rose and Steven Rose (eds)

The Radicalisation of Science Hilary Rose and Steven Rose (eds)

Theories of Underdevelopment Ian Roxborough

Marxism, Ideology and Literature Cliff Slaughter

Intellectual and Manual Labour: a Critique of Epistemology Alfred Sohn-Rethel

\section{FORTHCOMING}

Women's Oppression under Capitalism Olivia Adamson, Carol Brown and Judy Price

Stopping the Wheels Phil Cohen

The IQ Controversy Brian Evans and Bernard Waites

The Politics of Decline Andrew Gamble Anthropological Approaches to Pre-Capitalist Societies J. Kahn and R. Llobera
The Multinationals Richard Kronish

The State in Capitalist Formations Howard Wolpe

Corporate Liberalism Tony Woodiwiss

Towards a Critique of Political Economy Volume 1 The Theory of Crisis, Capital and the State

Volume 2 Imperialism and the Transition to Socialism David Yaffe 


\section{Marxism, \\ Ideology and \\ Literature}

Cliff Slaughter 
All rights reserved. No part of this publication may be reproduced or transmitted, in any form or by any means, without permission.

First published 1980 by

THE MACMILLAN PRESS LTD

London and Basingstoke

Associated companies in Delhi Dublin

Hong Kong Johannesburg Lagos Melbourne

New York Singapore and Tokyo

Typeset in $11 / 12$ Baskerville by

Styleset Limited, Salisbury, Wiltshire

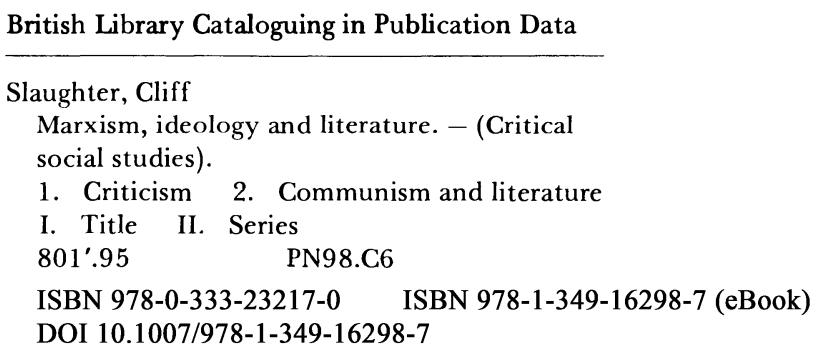

This book is sold subject to the standard conditions of the Net Book Agreement.

The paperback edition of this book is sold subject to the condition that it shall not, by way of trade or otherwise, be lent, resold, hired out, or otherwise circulated without the publisher's prior consent in any form of binding or cover other than that in which it is published and without a similar condition including this condition being imposed on the subsequent purchaser. 
To the memory of my father 


\section{Contents}

Acknowledgements

ix

1. Introductory 1

2. The Legacy of Marx 21

3. Literature and Revolution: Trotsky 86

4. A Man for all Seasons: Georg Lukács 114

5. The Hidden Structure: Lucien Goldmann 150

6. Against the Stream: Walter Benjamin 170

7. Conclusions: Literature and Dialectical Materialism

Notes and References $\quad 214$

$\begin{array}{ll}\text { Index } & 225\end{array}$ 


\section{Acknowledgements}

The quotations from Karl Marx, Grundrisse: Foundations of the Critique of Political Economy, translation () Martin Nicolaus 1973, are reprinted by kind permission of Penguin Books Ltd and Random House Inc.

I must also thank Jonathan Cape Ltd and Harcourt Brace Jovanovich Inc for permission to quote from Walter Benjamin, Illuminations, edited by Hannah Arendt and translated by Harry Zohn, copyright $\odot 1955$ by Suhrkamp Verlag, Frankfurt a.M., English translation copyright $\odot 1968$ by Harcourt Brace Jovanovich Inc.

Special thanks are due to Mrs Margaret Ellis and Mrs Jean Lister for their typing of the manuscript. Steven Kennedy and Timothy Fox were extremely patient and helpful in guiding the book through the press. My wife Vivien Slaughter shared the development of every theme in the book.

I cannot possibly single out individuals from the many friends and students whose work and comments have encouraged and contributed to whatever may be of value in these pages. It goes without saying that responsibility for its defects is mine and not theirs. Readers of the book will understand why I say that my greatest debt, shared with so many, is to those who gave their lives in the long battle for Marxism against its Stalinist and reformist enemies as well as against capitalism. 